\title{
Numerical Investigation on the Impact of Membrane Thickness on Transport Phenomena in PEM Fuel Cells
}

\author{
Shian $\mathrm{Li}^{1}$, Rongqiang $\mathrm{Wei}^{1}$, Guoling Zhang ${ }^{1}$, Yuanxin Qi ${ }^{2}$, Guogang Yang ${ }^{1, *}$, Qiuwan Shen ${ }^{1, *}$ \\ ${ }^{1}$ Marine Engineering College, Dalian Maritime University, Dalian, China; \\ ${ }^{2}$ Department of Energy Sciences, Lund University, Lund, Sweden; \\ *E-mail: yanggg@dlmu.edu.cn and shenqiuwan@dlmu.edu.cn
}

doi: $10.20964 / 2020.05 .15$

Received: 11 December 2019 / Accepted: 4 February 2020 / Published: 10 April 2020

\begin{abstract}
A two-dimensional mathematical model is used to investigate the performance and transport characteristics of PEM fuel cells with different membrane thicknesses. The overall cell performance of three cases are presented and compared. In addition, the local temperature, liquid water saturation, water content and current density distributions are analyzed and compared. Results show that performance increases with decreasing membrane thickness and the local transport characteristics is also significantly affected. The ohmic loss is mainly caused by the proton transport process inside fuel cell. And a thinner membrane can enhance water back diffusion process in the membrane which is beneficial to the water management at the anode side.
\end{abstract}

Keywords: PEM fuel cells, Membrane thickness, Cell performance, Transport characteristics

\section{$\underline{\text { FULL TEXT }}$}

(C) 2020 The Authors. Published by ESG (www.electrochemsci.org). This article is an open access article distributed under the terms and conditions of the Creative Commons Attribution license (http://creativecommons.org/licenses/by/4.0/). 